\title{
Retraction Note: Evolution of dissolved total solids in groundwater based on high resolution image processing and evaluation of urban English translation
}

Wanmei Liao ${ }^{1}$

Published online: 18 November 2021

(c) Saudi Society for Geosciences 2021

Retraction Note: Arabian Journal of Geosciences (2021) 14: 1683

https://doi.org/10.1007/s12517-021-08028-9

The Editor-in-Chief and the Publisher have retracted this article because the content of this article is nonsensical. The peer review process was not carried out in accordance with the Publisher's peer review policy. The author has not responded to correspondence regarding this retraction.

The original article can be found online at https://doi.org/10.1007/ s12517-021-08028-9.

Wanmei Liao

1wm227@126.com

1 International Business Department, Hainan College

of Foreign Studies, Wenchang, Hainan, China 